\title{
Intellectual limitation of freedom? The issues of libertas in the nationalistic reception of Italian fascism in the Second Polish Republic (based on the examples of journalistic publications)
}

The seizure of power in Italy by the National Fascist Party aroused understandable interest in Central European countries. ${ }^{1}$ The phenomenon of the emergence of a completely new state in terms of its system had to draw people's attention, while the "fascist model (...) was spreading throughout Europe due to the sole fact of its existence in the Apennine Peninsula." ${ }^{2}$ The efficiency of fascism was certainly inspirational for Polish politicians. The structure of Camp of Great Poland (OWP), established in December 1926, gathering anti-Sanation right wingers, resembled the Italian model (the organisation was governed by the Great Council, modelled after the Gran Consiglio Fascista operating in Italy ${ }^{3}$ ). Similarly, the May coup d'etat compellingly brought to mind the March on Rome from four years earlier, though unlike the latter it resulted in several hundred fatalities. However, the interest in Italian fascism was not only shared by politicians and army officials. In the 1920s and 1930s, there appeared many texts positively evaluating the ideology and the political system of Mussolini (or, at least, some of its elements ${ }^{4}$ ). The pro-fascist discourse was expressed in political treatises as

\footnotetext{
* Dr, e-mail: pmsobczak@interia.pl; Committee of Genetic and Documentary Research Into Litterature PAN/Łódź.

${ }^{1}$ The birth and the development of fascism was discussed in detail by Emilio Gentile in a book entitled Początki ideologii faszystowskiej (1918-1925), trans. T. Wituch, Wydawnictwa Uniwersytetu Warszawskiego, Warsaw 2011.

2 J.W. Borejsza, Rzym a wspólnota faszystowska, Książka i Wiedza, Warsaw 1981, p. 27. [English version translated from Polish].

${ }^{3}$ S. Rudnicki, Obóz Narodowo-Radykalny. Geneza i działalność, Spółdzielnia Wydawnicza „Czytelnik”, Warsaw 1985, p. 26. One of the more important symbols of the Youth Branch of OWP was the greeting in the form of a Roman salute.

${ }^{4}$ Jerzy W. Borejsza emphasised that "in the Poland of the interwar period, fascism was praised in dozens of brochures and books" (J.W. Borejsza, Mussolini byt pierwszy..., Czytelnik, Warsaw 1989, p. 182). Jacek Bartyzel noted that only in Gazeta Warszawska within the period from October 1922
} 
well as in columns, and foreign reports (as well as poems) written almost up to the end of the interwar period. For the purposes of this article, I limit myself to writing mainly about journalistic texts by the representatives of the national right (National Democracy (ND), young nationals, and Sanation right) reflecting on the socio-political and cultural themes. They began appearing in the mid-1920s since, as noted by Maciej Marszal, "the periodisation of the Polish interpretations of Italian fascism can be divided into two periods: the first until 1926, a time of thoughtless comments formulated by politicians and journalists who often, under the influence of the current politics of Benito Mussolini, offered explanations convenient for their groups; the second one after 1926, a time of mature analyses (...), which carried scientific value." ${ }^{5}$

Monika Bednarczuk aptly noted that "despite a thesis promoted by the left, particularly after 1945 , on the collective aversion to that political trend in the Polish interwar period, a considerable number of people saw desirable values in fascism." ${ }^{\prime \prime}$ Mainly people ideologically associated with the national right considered fascism with interest and sympathy. The new phenomenon, transcending existing political divisions, was interpreted in various ways. Very often, though, particularly in the 1920s, rightists viewed fascism as an effective means to repair, reconciling the interest of employees and big capital, and restoring (distorted in the final years of the Giolittian system) the socio-political order (Mussolini as a "rock which breaks the swollen waves of the Bolshevik torrent" ${ }^{\text {") }}$. The conservative vision of fascism was supported by the events from the first years of the rule of Duce, who was able to find accord between the king and the pope (the Lateran Treaty of 1929 establishing Catholicism as the official religion in Italy). ${ }^{8}$ Władysław Jabłonowski, an ND activist and a correspondent of Gazeta

to March 1923, there were published sixty articles favourably disposed to fascism ("Faszyzm" in: Encyklopedia biatych plam, vol. 6, Polskie Wydawnictwo Encyklopedyczne, Radom 2001, p. 85).

${ }^{5}$ M. Marszał, "Polskie elity wobec włoskiego faszyzmu 1922-1939", Annales Universitatis Mariae Curie-Skłodowska. Sectio G, Ius 2011, issue 58, pp. 121-122. [English version translated from Polish]. Also starting with 1926, there began to emerge (small and actually devoid of any political significance) groups referring to Italian fascism, e.g. Stronnictwo Faszystów Polskich (cf. a book by Olgierd Grott, Faszyści i narodowi socjaliści w Polsce, Zakład Wydawniczy Nomos, Krakow 2007).

${ }^{6}$ M. Bednarczuk, "Metafory faszyzmu (o polskich konceptualizacjach włoskiej doktryny)", Przeglad Humanistyczny 2011, issue 1, p. 18. [English version translated from Polish].

${ }^{7}$ R. Skirmunt, "Mussolini i Multiplikamini”, Stowo 1927, issue 190. As cited in: M. Marszał, op. cit., p. 125. [English version translated from Polish]. Bogumił Grott argued that "fascism was treated as a type of a roller which could crush the threats of the forces adverse to the Polish national interest, without sufficient understanding of its creative role" (B. Grott, Dylematy polskiego nacjonalizmu. Powrót do tradycji czy przebudowa narodowego ducha, Wydawnictwo Von Borowiecky, Warsaw 2014, p. 40 [English version translated from Polish]).

${ }^{8}$ The first programme Fasci Italiani di Combattimento of 1919 announced in Milan's Piazza San Sepolcro was saturated with leftist radicalism. It heralded, e.g. the removal of monarchy 
Warszawska (and the translator of Mowy Mussoliniego ${ }^{9}$ ), could, therefore, in 1926 with complete conviction state that "fascism awoke and aroused in the nation its better instincts and emotions: love for the homeland, pride in religious faith, familial feeling, the ability to sacrifice oneself, the love for work and social order, the realisation of the need for discipline and hierarchy, and, finally, state pride."'10 That conservative dream was contrasted with the vision of a revolution, according to which the fascist revolt became a radical gesture of shattering the existing world, and the futuristic destruction of that which was old, outworn, and rotten ${ }^{11}$ (its main exponent was Artur Maria Swinarski, the author of a collection entitled Eja! Eja! Alala! - a frenetic ode sung "for you, Benito and Gabriele!"12) Both views regarding the essence of fascism could coexist due to, as noted by Jerzy W. Borejsza, people's deficient understanding of the matter where "under the notion of 'fascist Italy' people applied their own various delusions and dreams, often far from the Italian reality." 13

Fascist Italy did not constitute a direct threat to independent Poland, while the respect for the culture and the lack of knowledge of Italian imperialism did not support such cautiousness as Polish intellectuals usually applied in relation to Germany. The lack of direct contact with the state of the Duce meant no increased sensitivity for the issues of authoritarianism, and the limiting of freedom and civic freedoms in Italy, which after 1926 were becoming increasingly severe (the special acts passed upon a series of assassination attempts on Mussolini, a radical limiting of the right to assembly, the dissolution of workers' unions and replacing them with syndicates, outlawing all political parties except Partito $\mathrm{Na}$ zionale Fascista, and the introduction of a new non-democratic election system

and the confiscation of church property, as well as changes improving the situation of labourers (cf. R. Eatwell, Faszyzm. Historia, trans. T. Oljasz, Dom Wydawniczy Rebis, Poznan 1999, p. 88). The establishing of Partito Nazionale Fascista coincided with the departure from the socialist ideas of Fasci, expressed in the programme from San Sepolcro and in The Charter of Carnaro by d'Annunzio. Right before the March on Rome, Mussolini announced that he recognised the need for the continued existence of the monarchy.

${ }^{9}$ Mowy Mussoliniego, trans. W. Jabłonowski, nakł. „Myśli Narodowej”, Warsaw 1927. [English version translated from Polish].

${ }^{10}$ W. Jabłonowski, Amica Italia. Rzecz o faszyzmie. Wrażenia i rozważania, Księgarnia Świętego Wojciecha, Poznan 1926. As cited in: J.W. Borejsza, Mussolini byt pierwszy..., p. 188. [English version translated from Polish].

${ }^{11}$ Cf. M. Bednarczuk, op. cit., pp. 26-27.

${ }^{12}$ A.M. Swinarski, “W prawo zwrot!” in: idem, Eja! Eja! Alala!, Instytut Wydawniczy „Arena", Warsaw 1926. As cited in: M. Bednarczuk, op. cit., p. 25. [English version translated from Polish]. In time, the Polish reception of fascism began to "gradually suppress the role of d'Annunzio, and the futuristic roots of fascism turning instead towards the apotheosis of a more realistic, yielding in relation to tradition, and a closer to the Polish traditions Duce" (J.W. Borejsza, Mussolini byt pierwszy..., p. 30).

${ }^{13}$ J.W. Borejsza, Rzym a wspólnota faszystowska, p. 27. [English version translated from Polish]. 
in $1928^{14}$ ). The limiting of personal freedom resulted directly from the fascist approach to the state-individual relationship. It was the state, personifying the national spirit (as per neo-Hegelian actualistic philosophy of Giovanni Gentile) that was considered the source and the subject of political power. ${ }^{15}$ In the social hierarchy constructed by fascist ideologists, the masses were placed at the very bottom while the state (basically its ruling elite with Duce at the helm), being the "only authentic expresser of the transcendent will of the spirit of the Italian nation"16, received the right to directly and deeply influence the personal lives of the citizens. The task of an individual, subject to fascist teachings, was to actively submit oneself to the state, associating oneself with the "political actualisation of the spirit" of the nation ${ }^{17}$, and, finally, the identification of one's own freedom as identification with the state. Therefore, within that idealistic construct of the Italian democrazia par eccelenza (where "the expression of the realisation of the political will of 'the few' or even 'the One' (...) was fulfilled in the consciousness and the will of 'all'"'18) there was no place for a liberally understood personal freedom outside the scope of state rule ${ }^{19}$ (though reality rarely reflected theoretical models, and military and church groups did not succumb to extensive fascistisation $\left.^{20}\right)$. The liberal idea of leaving the citizens the broadest individual freedom, and limiting state law activities to the minimum was completely alien to fascist ideologies. Freedom was interpreted by Gentile and Mussolini as a duty, while its scope and character had to be strictly limited by the state. ${ }^{21}$ It is worth consider-

${ }^{14}$ Cf. W. Kozub-Ciembroniewicz, Doktryna i system władzy Włoch faszystowskich na tle porównawczym, Wydawnictwo Uniwersytetu Jagiellońskiego, Krakow 2010, p. 46.

${ }^{15}$ W. Kozub-Ciembroniewicz, op. cit., p. 45. [English version translated from Polish]. In 1919, a nationalist politician Alfredo Rocco (later the minister of justice in Mussolini's government) wrote about "the absolute supremacy of the state, which is the organised form of the nation" - cited in: J. Sondel-Cedarmas, Nacjonalizm włoski. Geneza i ewolucja doktryny politycznej (1896-1923), Księgarnia Akademicka, Krakow 2013, p. 53.

${ }^{16}$ W. Kozub-Ciembroniewicz, op. cit., p. 45.

${ }^{17}$ Ibid., pp. 105-107.

18 Ibid., p. 113.

19 The liberal view of the state presumed, e.g. the subjective approach to the individual, a limiting and a division of political power, the social legitimisation of the authorities, a voluntary organisation of the state and the society, and the right of the ruled to oppose the state when their rights are not being respected ("Liberalizm" in: Doktryny polityczne XIX $i$ XX wieku, K. Chojnicka and W. Kozub-Ciembroniewicz (eds.), Wydawnictwo Uniwersytetu Jagiellońskiego, Krakow 2000, p. 14).

${ }^{20}$ The elements of idea-based pluralism visible in fascist Italy were discussed by Roger Eatwall, op. cit., pp. 131-132.

${ }^{21}$ As early as 1927 Antoni Peretiakowicz, a lawyer and a philosopher of law, noted that the fascist state offered the individual freedom only if it was compliant with the interest and the goals of the state. Thus freedom became not a principle and a goal (as in liberal concepts), but a method and a means (A. Peretiakowicz, Państwo faszystowskie: bilans rząów pięcioletnich, Dom Książki Polskiej, Warsaw 1927. As cited in: Amica Italia. Polscy prawnicy wobec włoskiego faszyzmu 1922-1939. Wybór pism, M. Marszał (ed.), Księgarnia Akademicka, Krakow 2004, pp. 99-100). 
ing whether and to what extent the problem of limiting freedom (mainly political, understood as a "zone in which man can act without any obstacles introduced by others" 22 , but also creative freedom) was significant for the Polish sympathisers of fascism. Whether the process of limiting civil liberties was accepted without any reservations, or whether people accepted it as the necessary price that was worth paying in the face of other values associated with fascism? In search of respective answers, I shall consider several important texts which focussed on or referred to Italian fascism, and which co-created its nationalist reception in the Second Polish Republic.

$$
* \quad * \quad *
$$

One of the first instances of profound interest in the political changes in Italy was a book by Władysław Jabłonowski entitled Amica Italia, published in 1926. According to Maciej Marszał, the text "reflected the essence of the Polish fascination with Benito Mussolini, and his socio-political views." ${ }^{23}$ Jabłonowski interpreted the fascist revolution as "curbing parliamentary wantonness," which

cured Italian parliamentarism, enabling the latter to fulfil its own activities without introducing continuous confusion in state life (..), and defined that form of parliamentarism which it should assume, that which it should fulfil if it wanted to be a truly useful factor in the state and the nation ${ }^{24}$

Therefore, fascism was to help cure the ills of political life in Italy by restoring the parliament to its rightful place - "an auxiliary institution (...), efficiently cooperating with the government, and not continuously developing intrigues

Thus the author noted the "almost complete removal of political freedom" (ibid., p. 112), while retaining considerable economic freedoms.

${ }^{22}$ I. Berlin, "Dwie koncepcje wolności”, trans. D. Grinberg in: idem, Dwie koncepcje wolności i inne eseje, J. Jedlicki (ed.), trans. H. Bartosiewicz et al., Res Publica, Warsaw 1991, p. 114. [English version translated from Polish]. Within the space of freedom, "the individual (...) possesses, or should possess, complete freedom and existing and acting according to their own will without the interference of others" (ibid., p. 114). Compulsion is understood by the philosopher as "an intentional interfering of others into my activities. One can talk about the lack of freedom or political liberties only when others prevent me from fulfilling my goals" (ibid., p. 115).

${ }^{23}$ M. Marszał, op. cit., p. 9. As noted by Anna Lew "the fascist doctrine appeared to Jabłonowski as a patriotic national restoration movement, as well as a special method for ensuring the victory of the national idea" (A. Lew, "Fascynacja czy akceptacja? Włoski faszyzm w poglądach Władysława Jabłonkowskiego", in: Narodowa Demokracja XIX-XXI wiek. Dzieje ruchu politycznego, vol. 1: Koncepcje-ludzie, T. Sikorski, A. Wątor (eds.), Wydawnictwo Adam Marszałek, Torun 2012, p. 326).

${ }^{24}$ W. Jabłonowski, op. cit. in: Amica Italia, M. Marszał (ed.), Krakow 2004, p. 1. 
against it." ${ }^{25}$ Several times the author condemned the "worshippers of the parliament" who absolutised its previous role. He also stressed Mussolini's ruthless fight against Masonry, which by putting itself above its own state destroyed the freedom of the individual. ${ }^{26}$ The Polish foreign correspondent viewed fascism as a "new national order" 27 , the formation of a state which "can only be national, while any other adjectives annexed to it (...) negate its essence." ${ }^{28}$ Those pursuits were hardly aimed against the freedom of the citizens as fascism was, in fact, as Giovanni Gentile argued, "the optimal form of democracy" 29 , which reconciles the interest and the pursuits of the nation with actual liberties:

(...) Mussolini is, in fact, a better democrat than ex officio democrats (...). He is more honest a liberal than sworn liberals as he does not slavishly kneel before the rather denounced god of abstract freedoms (...), he rather strives to ensure the same actual freedoms, such as freedom of the press, possession, conscience, etc., for all, without which societies do not progress, and become dependant on others in material and spiritual terms ${ }^{30}$

The theses posed by Jabłonowski, which offered an enthusiastic approval of Mussolini's political reforms, confirmed that in the mid-1920s, there was a clearly visible departure among the nationalists from democratic traditions, which once enabled parties to gain the support of rural and urban classes. Zygmunt Wasilews$\mathrm{ki}$, an ND journalist and $\mathrm{critic}^{31}$, stated bitterly: "we were engaged with all seriousness (maybe too long and too exclusively) in politics, lawfulness, constitutionalism, and parliamentarism" while the Bolshevik "Asia is laughing that someone is expecting a fight on the foundation of parliamentarism." ${ }^{32}$ In the face of a new threat, "the masters of the parliamentary tactics, the doctrinaires of democracy, the technicians of political opportunism will make no difference here" ${ }^{33}$, and Italians were the first to realise that. Therefore, rightist communities, among which

${ }^{25}$ It is noteworthy that Jabłonowski's book had been published two years before the electoral system was changed, which reduced the Italian parliament to the role of a façade of the previous institution.

${ }^{26}$ W. Jabłonowski, op. cit. in: Amica Italia, pp. 3-4.

${ }^{27}$ Ibid., p. 4.

${ }^{28}$ Ibid., p. 10.

${ }^{29}$ Cf. W. Kozub-Ciembroniewicz, op. cit., p. 52.

${ }^{30}$ W. Jabłonowski, op. cit. in: Amica Italia, p. 14.

31 The interwar evolution of Wasilewski's views in terms of culture was discussed by Eugenia Prokop-Janiec, Literatura i nacjonalizm. Twórczość krytyczna Zygmunta Wasilewskiego, Universitas, Krakow 2004, pp. 334-350.

32 Z. Wasilewski, “O uzgodnienie terenu”, Myśl Narodowa 1927, issue 17, p. 301. [English version translated from Polish].

${ }^{33}$ Ibid., p. 302. 
the concept of the rule of the nationalist elite was becoming increasingly popular, observed with considerable interest fascist Italy ${ }^{34}$, from time to time publicly expressing their support for Mussolini's policy (Władysław Kozub-Ciembroniewicz stressed that the establishing of OWP "created in Poland the conditions for the reception of the ideological and political principles of Italian fascism" ${ }^{35}$ ). The assassination attempt on Duce in April 1926 impelled the parliamentary board of the Club of the Christian-National Party (Klub Stronnictwa Chrześcijańsko-Narodowego) to draw a resolution in which Italy was defined as "the chief protector of the civilisation, and social and political peace in Europe"36, while National Democrats established strong contacts with the Italian fascist movement. ${ }^{37}$ Roman Dmowski, the leader of ND, visited Rome in the spring of $1926^{38}$, and a few months later he issued a letter to the nationalistic writer and politician Enrico Corradini ${ }^{39}$ (in French). In the letter, a copy of which was sent to Mussolini, Dmowski unequivocally indicated Mussolini's Italy and the fascist structure of the society as an inspiration, and a model to be emulated in his own political activities ("I am certain that my country will be one of the first ones which in terms of their internal organisation shall follow your lead" ${ }^{\prime 40}$ ).

However, it soon became evident that "after 1926, Rome valued its relations with the ruling party higher than those with National Democracy, and the organisations which stemmed from it." ${ }^{, 11}$ In the ND community, there become pronounced

${ }^{34}$ Bogumil Grott assessed that the fascist system functioning in Italy "was considered by the national party as the first ever case of fulfilling the principle of the rule of the 'national elite', and thus was initially evaluated positively" (B. Grott, op. cit., p. 154).

${ }^{35}$ W. Kozub-Ciembroniewicz, op. cit., p. 214.

${ }^{36}$ J.W. Borejsza, Mussolini byt pierwszy..., p. 175. [English version translated from Polish].

${ }^{37}$ It was Jacek Bartyzel's opinion that the leading ND politicians "derived their knowledge on the essence and the goals of fascism from their Italian friends, nationalists (...); that was also the source of their conviction that fascism was only a more dynamic form and manifestation of the pursuits of traditional nationalism; that resulted (...) in a general sense of a unity of goals and values with Italian fascism" (Faszyzm, p. 85).

${ }^{38}$ Also in 1926, Dmowski published in Gazeta Warszawska a series of articles devoted to Italian fascism.

${ }^{39}$ Enrico Corradini was the creator of the first Italian nationalist periodical, the $I l$ Regno, the first issue of which appeared in 1903. In 1910, he established Associazione Nazionalista Italiana; he was also one of the initiators of the merger of that organisation with Partito Nazionale Fascista (1923). Upon Mussolini's rise to power, he was appointed a lifetime senator. His major work, L'unità e la potenza delle nazioni [Unity and Power of the Nation], was published in Polish (Jedność i potęga narodu) in 1937 (six years after his death). His biography and views were discussed by Joanna Sondel-Cedermas, op. cit., pp. 167-193.

${ }^{40}$ As cited in: J.W. Borejsza, Mussolini byt pierwszy..., p. 179. In his articles, Dmowski stressed, though, the special nature of the political methods of fascism, which were specifically Italian, and as such could not be emulated by Poles (cf. W. Kozub-Ciembroniewicz, op. cit., p. 216).

${ }^{41}$ J.W. Borejsza, Mussolini byt pierwszy..., p. 190. It seems prudent to note, though, a complete lack of Poles' engagement in any activities promoting international fascism (the CAUR organisation, 
a dissonance towards Italian fascism, particularly in relation to the possibility of transferring it onto the Polish reality. Roman Rybarski, a valued economist (as well as a politician), though considering Mussolini as a "grand educator of the nation" as liberalism or socialism were, which had one model, which was to be applied in China and Poland alike." Therefore, the emulation of the Italian solutions could only be possible "when one becomes convinced that only such a solution is the result of the actual needs of our national economy." ${ }^{\text {"43 }}$ Several years later, though not referring to fascism directly, Rybarski warned against "a national police state", which while proclaiming the omnipotence of the state "takes away independence and private life from everything that remained between the individual and the state." ${ }^{44}$ Such a method of fighting individual rights would lead to "society's atomisation, i.e. to that which is the stepping stone for liberalism (...)"45 Instead, the national state promoted in press articles should replace the liberal individualism through bottom-up organised institutions (local self-governments, associations, religious associations, etc.) understood as "an expression of national life, and the source of the solid power of the state." The violation of individual freedom should not lead to equalling the "power of the state" with the "power of the government"

and the international congress in Montreux), which propagated the universal nature of the fascist doctrine, and the cooperation of organisations from specific countries.

${ }^{42}$ R. Rybarski, "O dyktaturach”, Myśl Narodowa 1927, issue 21, p. 382. [English version translated from Polish].

${ }^{43}$ Ibid., "Polityka gospodarcza faszyzmu", Gazeta Warszawska Poranna 1926, issue 190. As cited in: Amica Italia, p. 58. That thought resurfaced in ND articles several times; ten years later, Henryk Eysymontt (a proponent of the view that a monarchy is "the fullest form of a national state") noted: "We are always far too impressed by foreign matters, and as a result we now have too much uncritical enthusiasm for a fascist or Nazi form of national state. That sometimes offers the convenient conviction that thus Germans or Italians have already done the job for us, while we can without any significant intellectual effort transfer to us foreign patterns. While in fact we need to consider the things at our own discretion, without forgetting that those countries shaped the national state according to their conditions, while we need to do it according to ours" (H. Eysymontt, "O ideał ustroju. Polemika z powodu artykułu 'Monarchia czy państwo narodowe"”, Myśl Narodowa 1936, issue 19, p. 292 [English version translated from Polish]).

${ }^{44}$ R. Rybarski, “O państwie policyjnym”, Myśl Narodowa 1933, issue 20, p. 274. [English version translated from Polish]. Ryszard Piestrzyński was similarly critical in his evaluation, from the nationalist point of view, of the transformation of the absolutist system into an omnipotent police state: "Police systems cannot stand next to them any social forces, independent in their scope. They need to subjugate them (...) Police systems also destroy human character. They wish to rule through fear, through absolute bereavement of humans of their own thoughts and views on the fate of the country, which leads to depriving them of their sense of responsibility, and readiness to defend national interests. While the intention of nationalism is to develop a natural sense of responsibility for the country in the entire nation, and develop a healthy social system" (R. Piestrzyński, "Państwo absolutystyczne i jego zwyrodnienie", Myśl Narodowa 1933, issue 13, p. 163 [English version translated from Polish]).

${ }^{45}$ R. Rybarski, “O państwie policyjnym”, p. 274. [English version translated from Polish]. 
(and that was exactly what happened in Italy). Rybarski's train of thought could be concluded in the statement that

A criticism of liberalism does not automatically lead to a situation where every system which rises from the rubble of a liberal state should be considered an expression of a national system. (...) If one sees in the idea of the rights of an individual an assumption which is contrary to the foundation of the national trend, then also the life of a police state can assume forms which remain in evident contradiction to that trend. ${ }^{46}$

From the early-1930s, the ND community began to approach Italian fascism with increasing distance. ${ }^{47}$ They criticised Hegelian absolutisation of the state, excessive collectivism, and they already noticed the discrepancies and the conflicts between the state pursuing omnipotence and the Church..$^{48}$ Dmowski himself, though recognising the achievements of fascism as a national movement ${ }^{49}$, viewed with aversion the excessive militarisation of the politics in Italy, which resulted in a blind submission to the leader, and a decline of any free political thought. ${ }^{50}$ At the end of the interwar period, National Democrats already noted the "deterioration of fascism, and the demise of Mussolini's greatness" ${ }^{51}$, seeking ideological suggestions rather in the conservative authoritarianism of Salazar and Franco (more aligned with the Catholic traditionalism of the ND youth). Italian fascism

${ }^{46}$ Ibid., p. 273.

${ }^{47}$ Yet there were many exceptions. In 1937, Władysław Jabłonowski wrote about the "generous and heroic spirit, which first tore Italy out of the void of Bolshevik atrocity, and then introduced order and discipline in all areas of national life, awoke zeal for work, improved the country's material and moral condition, and prepared it for grand tasks and purposes" (W. Jabłonowski, "Italia żyjąca", Myśl Narodowa 1937, issue 19, p. 292). He described Mussolini as "the one (...) who by strengthening the powers of the nation, and putting grand goals for it to achieve, tore it from the mediocrity of existence, and helped it raise its head proudly." (ibid.)

48 Olgierd Grott noted that ND politicians "only at the brink of the 1930s, managed to notice that the system of Italian fascism, and its doctrine are not actually based on Catholic principles, while the state remains in clear opposition to the Catholic Church" (O. Grott, op. cit., pp. 260-261).

${ }^{49}$ Dmowski emphasised that Italian fascism was "an honest attempt at building a solid future for the homeland, it went to great lengths to oust the factors of moral and religious decay from national life" (R. Dmowski, "Hitleryzm jako ruch narodowy" in: A.S. Kotowski, Narodowa Demokracja wobec nazizmu i Trzeciej Rzeszy, Wydawnictwo Adam Marszałek, Toruń 2007, p. 165).

${ }^{50}$ R. Dmowski, "Militaryzacja polityki”, Gazeta Warszawska 1934, issue 247, 249, 250, 252-254.

${ }^{51}$ K. S. Frycz, "Na widowni”, Myśl Narodowa 1939, issue 18, p. 265. The author saw the cause of the negative evolution of Mussolini's policy in the socialist intellectual formation of Mussolini, as a result of which "in its profoundness fascism as a doctrine was not actually an important and based on the historic tradition emanation of the spirit of the Italian nation, rather an Italian-conceived adaptation of the socialist teachings of Marx for the national purposes (...) Fascism was often dualistic, and when nonetheless it did not decide to clearly and emphatically stand with Rome and the Church, the uncompromising and completely anti-Roman and anti-Catholic Nazism gained a spiritual advantage over it" (ibid.) 
was studied with more interest by young national communities, usually ideologically congenial to the ABC National Radical Camp (Obóz Narodowo-Radykalny $\mathrm{ABC}) .{ }^{52}$ Young nationalists, usually critical of ND politicians, like the latter earlier, treated fascism as an inspiration, and a point of reference in their own thinking. ${ }^{53}$ Jan Korolec did, in fact, in 1935 write that Italian fascism "was not able to reconcile the need to introduce order and the preservation of the freedom of an individual, which was the foundation of its creation. Fascism, being a proponent of the omnipotence of the state, cannot ensure people as much freedom as they need to be creative. ${ }^{54}$ However, Alfred Laszowski, a journalist and a literary critic of Prosto z mostu, condemned the attitude of the "weepy humanitarians", who perceived total systems in a one-sided manner:

The role of dogma is played in a given case by a bromide. We all know it by heart: Totalism, i.e. prison, torment and torture, totalism destroys individual freedom. Capitalists terrorise the working class to be able to retain power (...) A bat, that is the symbol of fascism, reaction, ignorance, and backwardness. The place where bloodthirsty ruffians rule is where the civilisation reaches its end, and the artist dies, or writes following the instruction of the regime. Try to express a doubt - they will drown you in their shouts, they will quote, and the list of the forty martyrs shall live again in the memory. ${ }^{55}$

Łaszowski argued that violence, cruelty, and limiting one's freedom does not exhaust the notion of totalism, "which is, obviously, quite extensive and

52 In Maciej Urbanowski's opinion "fascism, particularly in its Italian version, evoked intense though not uncritical interest among young nationalists" (M. Urbanowski, "Prosto z mostu" in: idem, Oczyszczenie: szkice o literaturze polskiej XX wieku, Wydawnictwo Arcana, Krakow 2002, p. 73).

53 The journalists of Prosto $z$ mostu postulated the rejection of the minimalist passive approach to reality, they contrasted voluntarism with the contemplative approach, while they intended to substitute pragmatism with intellectual idealism ("Only in action can we see the essence of things. Deeds are the proper cognitive acts, conditioning reality, and assigning it a direction for its development," argued Alfred Łaszowski, "Analiza łez krokodylich", Prosto z mostu 1937, issue 47, p. 2). That attitude displayed a visible inspiration of the neo-idealistic philosophy of Giovanni Gentile, who rejected the "abstract and intellectual" philosophy, and propagated that expressed through deeds (cf. Doktryny polityczne..., p. 346). The journalists had an ambivalent approach to fascism itself: on the one hand, they emphasised their common principles, on the other, they expressed a conviction of the need for improving the fascist ideas, mainly through assigning them a Catholic character ("the totality of the Catholic idea, represented by the future Poland, carries national freedom based on a unity of the approach to God, and the realisation of God's order on Earth") (S. Piasecki, “Trzy morza a nie jedno", Prosto z mostu 1939, issue 17, p. 1 [English version translated from Polish]).

54 J. Korolec, "Czy słowo zaklęcia będzie wypowiedziane po polsku”, Prosto z mostu 1935, issue 3, p. 4.

${ }^{55}$ A. Łaszowski, “Analiza łez krokodylich", Prosto z mostu 1937, issue 45, p. 1. [English version translated from Polish]. 
complex"56 ("If fascism was one big slaughter house and a torture chamber, it would not have been able to organise the collective mind in such a degree as it is doing now"57). He also claimed that "the acts of cruelty go hand in hand with historic deeds," while "the image of carnage obscured for the liberals a more profound meaning of the existence of total systems." ${ }^{58}$ Laszowski's interpretation was based on the underlying conviction that "a system founded on detriment can create positive values, even though any detriment evokes a condemning and opposing reaction." ${ }^{59}$ Thus the journalist realistically assumed that the violence of the state against an individual "constitutes a necessary and inevitable evil" ("A politician knows that it has never been any different. Either we hurt others, or others strike us as hard as they can"60).

Thus the issue "to whom the violence applies, and what does it prevent, what does it compensate for in total systems" ${ }^{\prime 61}$ became of key importance for an evaluation of the political system of a country. In the late-1930s, violence increasingly turned against Jews corresponding to the anti-Semite convictions of young nationalists ${ }^{62}$, and confirming Jan Rembieliński's view that "nationalism in Europe, only because it is a national movement, by definition must liquidate yids (...)"63 The turn of Italian fascists towards racism and anti-Semitism (made in the late1930s) was regarded highly. ${ }^{64}$ La doctrina del fascismo (initially an entry in Enciclopedia Italiana, whose authorship was ascribed to Mussolini ${ }^{65}$ ) published in 1932, was still free of any anti-Semite taint, while Duce himself in an interview by Emil Ludwig argued that "national pride does not need the racial insanity...

\footnotetext{
${ }^{56}$ Ibid.

57 A. Łaszowski, “Analiza łez krokodylich”, Prosto z mostu 1937, issue 47, p. 2. [English version translated from Polish].

${ }^{58}$ That idea Łaszowski seemed to explain in the further part of his text: "Totalism fights pluralistic concepts. It wants to derive all phenomena from a single superior principle. It integrates, unifies, combines, and binds the nation using violence and power. It accentuates similarities while ousting differences. The dominance of structural tendencies over atomistic ones should be considered as the proper fabric of those movements. Fascism stemmed from indeterminism. Its whole practice proves that a strong individual is not determined by the set of objective conditions, that power itself releases, transforms, and creates" (ibid., p. 2).

${ }^{59}$ Ibid., "Analiza łez krokodylich", Prosto z mostu 1937, issue 45, p. 1.

${ }^{60}$ Ibid., p. 2.

${ }^{61}$ Ibid.

${ }^{62}$ Cf. M. Domagalska, Antysemityzm dla inteligencji? Kwestia żydowska w publicystyce Adolfa Nowaczyńskiego na łamach „Myśli Narodowej” (1921-1934) i „Prosto z mostu” (1935-1939) (na tle porównawczym), Żydowski Instytut Historyczny, Warsaw 2004, pp. 103-130.

63 J. Rembieliński, "Na widowni”, Myśl Narodowa 1934, issue 1, p. 11. [English version translated from Polish].

${ }^{64}$ Roger Eatwell explained Mussolini's turn towards anti-Semitism as an attempt to find a new "factor for regenerating fascist radicalism" (R. Eatwell, op. cit., p. 134).

${ }^{65}$ Probably Giovanni Gentile was the actual author.
} 
There is no anti-Semitism in Italy." ${ }^{96}$ It was only in 1938 that the Manifesto of Race was published; it included, e.g. theses on the Arian nature of Italy, and the existence of the "pure Italian race", and it proposed a policy of racial separatism in the name of defending European characteristics of Italians. ${ }^{67}$ The introduction of racial acts, over fifteen years after the March on Rome, was usually interpreted as a proof of the subjugation of Italy to the ideological and political influences of the Third Reich. However, Karol Zbyszewski argued that

Mussolini as an ingenious man never liked Jews, he had been fighting them for a long time, Yids who worked in culture would find a note on their desk in the morning: your resignation has been approved!, and the caretaker would lead them down the kitchen stairs and out the door. It is only in our country that education, literature, and civilisation cannot do without Jews. According to certain factors, of course. ${ }^{68}$

That mode of thinking suggested that the Jews living in Italy were not entitled to civil liberties. The national state and its leader were the sovereign, which was why fighting Jews justified with the need to fulfil Italian national interests did not arouse any public opposition.

In the late-1930s, the issue of freedom of literature and culture in totalitarian countries, in the fascist Italy in particular, became widely debated. Alfred Łaszowski argued that "today, totalism releases such energy which proves that the relationship of the artist with a given state can possess all the characteristics of creative freedom," whereas

emphasising the discrepancies between the state and writers is beneficial to Jews. They work to develop the rift, that is the essence of their destructive role. An artist rooted in a familial foundation will not feel the need to express any matters which could undermine the sense of its existence. Even negation and criticism fall in line with the objective interests of a country ${ }^{69}$

\footnotetext{
${ }^{66}$ As cited in: Doktryny polityczne..., p. 356. One of the most prominent figures of PNF was, at that time, Ettore Ovazza, the son of a Jewish banker.

${ }^{67}$ W. Kozub-Ciembroniewicz, op. cit., p. 161. It is noteworthy that the manifesto did not proclaim an official hierarchic ordering of the races; individual races were supposed to be different from one another, yet neither better or worse.

${ }^{68}$ K. Zbyszewski, "Ryżową szczotką. Blok zdrowego sensu", Prosto z mostu 1938, issue 39, p. 8. Also Adolf Nowaczyński considered as one of the "thousand lies and offences" cast against the fascist Italy the conviction that "the severe anti-Hebrew trend, that second-hand, that emulation of the last two years to impress Berlin, that it has never been foreshadowed, that it is mocking and parroting Germans" (A. Nowaczyński, "Ofensywa. Sempre avanti”, Prosto z mostu 1939, issue 10, p. 8 )

${ }^{69}$ A. Łaszowski, “Analiza łez krokodylich”, Prosto z mostu 1937, issue 47, p. 2.
} 
The issue was discussed in more detail by a collaborator of Prosto z mostu, Adolf Nowaczyński. The author of Skotopaski sowizdrzalskie had already often evaluated Italian fascism positively in texts published in Myśl Narodowa, ascribing it with a "ruthless yet systematic [pursuit] (...) of increasing the morality of the entirety of life in all its areas"70, care about women's dignity, and healthy morals amongst the youth. In the late-1930s, Nowaczyński proved that under Mussolini's rule artistic creativity did not vanish, as it was suggested in the texts of many Polish journalists (or, in fact, "compositions (...) of youngsters muttered exactly according to the instructions of Semite teachers and tricksters" ${ }^{\prime 71}$ ). In fact, it was the contrary: some areas of the arts (such as music, opera, and sculpture) blossomed extensively, and in that view fascist Italy could constitute an unequalled role model for Poland. The writer called any opposing statements as "insolent and vile" lies propagated by Jews who "slander Italy" in order to take revenge on the recently introduced anti-Semite repression:

Therefore, a lie flowing along the waves of "poisonous Jewish gases" is the bromide that under "dictatorship" the life of Art, Literature, and Theatre dwindles and dies. Architecture, Sculpture and Music entered together with Mussolini into an era of a new Renaissance. Less so with Poetry, Novels, and Drama. Yet the pulse of life and creative dynamics are still at a high level, and for us... unachievable in terms of their dynamics. $^{72}$

Nowaczyński also stressed the clearly visible propagation and democratisation of culture (mainly thanks to the Opera Nazionale Dopolavoro organisation), thanks to which a common phenomenon were "operas in market squares, popular concerts amongst ruins where labourers listened together with their wives ("art literally became domesticated, it went out to the working class, and it became the basic component of everyday life of the entire peoples of physical workers"73). In the cultural life of Italy, the writer saw a free exchange of thoughts, "life, temperament, fervour, fire", and "fertility, love, and freshness." He failed to notice, though, the restraining of creative freedom, and its subjugation to the interest of the fascist regime. Therefore, he proclaimed his Italophilia supplementing his

${ }^{70}$ A. Nowaczyński, “Ofensywa. Caliban zabił Ariela”, Myśl Narodowa 1930, issue 45, p. 715. [English version translated from Polish]. The columnist praised extensively Duce's care for the high level of morality of his nation: "Mussolini applies the greatest care to the morals and the sexual lives of adolescents. In schools, there is a ban, violators of which are punished severely, on using obscene and vulgar language, as well as cursing and insults. There is also a ban on using filthy speech in army barracks." (ibid.)

${ }^{71}$ A. Nowaczyński, "Ofensywa. Sempre avanti”, p. 8.

72 Ibid.

${ }^{73}$ Ibid. 
peculiar Francophobia: "Everything we have ever taken from Italy was positive and constructive. While anything we take from Paris today is well-perfumed manure." ${ }^{74}$

It must be noted, though, that Nowaczyński's play entitled Cezar $i$ człowiek, written several months prior, presented the problems of the relationship of culture and dictatorship somewhat differently. The story of the 1937 work was set in Rome at the turn of the $16^{\text {th }} \mathrm{c}$. (yet some historical elements were altered rather freely), and it centred around a surprising concept of the love between Lucrezia Borgia and Nicolas Copernicus. The Polish "stargazer" was presented therein as a personification of the freedom of the human spirit attempting to discover the truths about the world and cosmos freely and uninhibitedly ("In fact, human spirit is endless, while the human mind pursues mysteries, therefore ad astra! ad astra! it will strive until it discovers what is hidden"75). Copernicus's antagonist was Cesare Borgia, whose political intention was to conquer and unite Italy under his rule (so that there is "one duce", not a hundred), while the means towards that goal: terror and brutal violence. Prince Borgia was presented as an uncompromising proponent of the strong rule of an exceptional individual willing to subjugate everything and everyone ("Now you see for yourselves! Give the nation a little slack, and this is what happens. One person is capable of keeping it all in check. Either libertas or discipline, either autoritas or what: The Orsinis, uproar, trouble, rebellion, "homo homini lupus'..." Copernicus's intellectual independence and personal courage became in those conditions the reason for issuing a death sentence on the astronomer. Saving himself in a dramatic escape, Copernicus managed to be triumphant: a few years later Man was celebrated in Ferrara, while the once omnipotent Emperor died a shameful death. Nowaczyński's historical fantasy was (both by his contemporaries and years later) read in the context of the political situation of the second half of the 1930s as an illustration of the "threat to grand spiritual values carried by tyranny, criminal political rapacity, and brutal military rule", and, rather surprising considering the writer's creative biography, "a warning against fascism." 77 In a review of a staging of the play at Teatr Nowy, Antoni Słonimski argued:

Nowaczyński's new play is quite an extraordinary event (...) The propagator of nationalistic, fascist and anti-Semite slogans could easily live off of his long-term activities. There came the time when Nowaczyński's ideology has finally received its rather universal triumph (...) But Nowaczyński is an artist. Not only the perverseness

\footnotetext{
${ }^{74}$ Ibid.

75 A. Nowaczyński, Cezar i człowiek, Gebethner i Wolff, Warsaw 1937, p. 128. [English version translated from Polish].

${ }^{76}$ Ibid., p. 202.

77 J. Kwiatkowski, Dwudziestolecie międzywojenne, Wydawnictwo Naukowe PWN, Warsaw 2000, p. 429.
} 
of a pamphleteer, but a more profound thing: his artistic instinct suddenly tossed him against the victorious wave of the incoming barbarity. (...) Nowaczyński juxtaposed the raison d'etre, brutality, and violence with humanity and the Promethean want of knowledge, which cannot be blocked either by the crimes of the tyrant or the stake of the inquisitor. ${ }^{78}$

Słonimski noted that the "lofty ideology" of the play contradicted the many years of the journalistic work of the author of Góry z piasku. For him, Cezar $i$ człowiek mainly confirmed his own conviction of the "impossibility of reconciling fascism with the most important element of art always devoted to the notion of humanity." 79 That was why he was willing to treat with increased understanding the linguistic and narrative failings of the playwright; considering the ideological reading of the text, it was of a lesser significance that "in reality a Lucrezia Borgia would not take any notice of a Copernicus." 80

The attitude of Jerzy Waldorff in the late-1930s did not evoke similar remarks and comments. The music reviewer and a journalist of Kurier Poranny, and a collaborator of Prosto z mostu (where he published an interview with Leon Degrelle, the leader of the Belgian fascist organisation Christus Rex), in the summer of 1937 travelled to Italy. He shared his experiences of his visit in fascist Italy in a series of articles published in Stanisław Piasecki's weekly, and later collected in a book entitled Sztuka pod dyktatura (it was published at the beginning of 1939, after Waldorff had left Prosto $z$ mostu) ${ }^{81}$. The starting point for the story of the culture of contemporary Italy was the introduction of a vital division into Italian and German fascisms. Waldorff emphasised (also quoting Martinetti, whom he visited during his visit in Italy) the completely different approach of both dictators to the arts and artists. While Hitler strictly condemned the avant-garde and crippled any free artistic criticism, Mussolini did not display any animosity towards modern culture. On the contrary, Duce remembered that it was avant-garde artists that paved the way for the new political system ("The fascist revolution has been the only case in history when (...) art prepared the revolution"82). Therefore, he left creators considerable freedom for their actions provided that they formally

\footnotetext{
${ }^{78}$ As [Antoni Słonimski], “Sztuki o Koperniku i Villonie”, Wiadomości Literackie 1937, issue 26, p. 5 [English version translated from Polish].

${ }^{79}$ Ibid.

${ }^{80}$ Ibid.

${ }^{81}$ The image of Italian culture as presented in Waldorff's book was analysed at length by Arkadiusz Meller, “'Sztuka pod dyktaturą' Jerzego Waldorffa - szkic o relacjach między faszyzmem a kulturą na przykładzie Włoch Benito Mussoliniego", Historia i Polityka 2009/2010, issue 2/3, pp. 105-121. The text is available online: Akademicka Platforma Czasopism [online], http://apcz.pl/ czasopisma/index.php/HiP/article/view/HiP.2010.007/1357 (accessed on 10.02.2016).

82 J. Waldorff, "Sztuka pod dyktaturą. D’Annunzio - Marinetti”, Prosto z mostu 1937, issue 55, p. 3. [English version translated from Polish]
} 
accepted the fascist system. ${ }^{83}$ Without interfering with any matters of aesthetics ("Duce's wisdom consists of not considering himself too wise, and not making statements on aesthetics. "That is for artists to decide" ${ }^{84}$ ), the authorities had a goal of efficiently organising the cultural life and its institutions. The wide-scale state patronage astonished Waldorff ("I had never expected your government to assume (...) a position which cannot be referred to any longer as 'supporting', rather as 'cultural armament' of Italy" ${ }^{\prime 85}$ ). He also admired, something Nowaczyński also appreciated, the promotion of culture among the broad masses of the Italian society ("Labourers and peasants are listening to Sophocles, Euripides, and

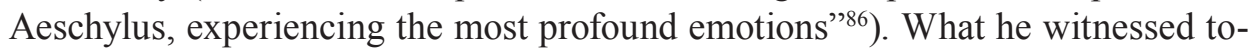
gether with the meetings with Italian artists and notables (Waldorff was received by the minister of propaganda, and he was escorted by three officials ${ }^{87}$ ) convinced him that the common visions and opinions echoed by the liberal elites of Warsaw were completely false: "At Ziemiańska, it is not befitting to criticise the scheming of American capitalists, but it is obligatory to preach nonsense about the dreadful tyranny of Mussolini, even if one does not know what that tyranny was to consist of. It is totalism, so there must be tyranny. End of story!" 88

Jerzy Waldorff understood that in order to develop, art needs freedom. He thought that the fascist state guaranteed that essential portion of creative liberty.

${ }^{83}$ Alfred Jesionowski, who reviewed Waldroff's book in Prosto z mostu, argued that even the limitations (of political nature) posed for creators by the regime could be utilised to benefit Italian literature: One could add here that such an extensive limitation regarding the social reality requires true creators who possess God-given talent, to apply much more effort, and be more original than writers for whom all themes are accessible, who thus almost exclusively delve into the bleak reality of everyday life, they cannot exit the tight circle surrounding their world of minor things, and thus in their psychological analyses they resort to distortions and artificiality, which will never reach mass consumers, and will remain only a peculiarity for a small group of literary enthusiasts" (A. Jesionowski, “Zbrojenie kulturalne Italii", Prosto z mostu 1938, issue 10, p. 7).

${ }^{84}$ J. Waldorff, "Sztuka pod dyktaturą. Rzeźba włoska”, Prosto z mostu 1938, issue 6, p. 3. [English version translated from Polish].

${ }^{85}$ Idem, "Sztuka pod dyktaturą. Caffe Greco", Prosto z mostu 1938, issue 14, p. 2. [English version translated from Polish]. Waldorff was often critical about the cultural policy of the Polish government, e.g. when writing about his sculptor friend, he noted that he was "a scholarship recipient of the Polish government, so he has enough money not starve to death, yet too little to live" (idem, "Sztuka pod dyktaturą. Rzeźba włoska", p. 3).

${ }^{86}$ Idem, "Sztuka pod dyktaturą. Teatr włoski”, Prosto z mostu 1938, issue 17, p. 3. [English version translated from Polish]. Alfredo Casella, quoted extensively by Waldorff, assured: "Artists throughout Europe complain that people have lost their desire for art, and that they continue to depart from art. In Italy it was the same thing. But fascism instead of whining said to itself: if you don't want art, then we'll come with it to you!" (idem, "Sztuka pod dyktaturą. Muzyka", Prosto z mostu 1937, issue 57/58, p. 12).

${ }^{87}$ M. Urbanek, Waldorff. Ostatni baron Peerelu, Wydawnictwo Iskry, Warsaw 2008, p. 61. [English version translated from Polish].

${ }^{88}$ J. Waldorff, "Sztuka pod dyktaturą. Architektura", Prosto z mostu 1938, issue 8, p. 2. [English version translated from Polish]. 
He noticed, though, that the omnipotence of the state in the area of organising cultural life, and the lack of ability to act outside the official state structures may negatively affect the development of artists' talents. The identified deficiencies of Italian culture (e.g. the low level of poetic compositions) did not, though, considerably influence the general reading of the text, which presented fascist Italy as a country which valued art and literature highly, cared for its development, and did not impose on the creators a rigid ideological girdle. Mussolini's government did not repress artists unfavourably disposed towards fascism, or was even magnanimous towards them:

Even before leaving the country, Toscanini was known for his anti-fascist views, everyone knew about it. He did not want to conduct Giovinezzo's hymn, so he did not do it - no one forced him otherwise. (...) But after the concert and regular ovations, when the conductor was stepping into the street, a few thugs lunged at him, and slapped him. Obviously, those were some scallywags operating on their own inspiration. Their actions were widely condemned. Yet, mortally offended, Toscanini left the country, and has been twice as abusive of fascism, and does not want to come back. But he could! Duce still considers him such a great artist that now, quite recently, our conductor demanded for a festival in Austria three soloists, contracted in Italy - he personally ordered the termination of their contracts, so that they could satisfy the fantasy of Toscanini, the relentless opposer of fascism. That is the reality of the pressures exerted by the government. ${ }^{89}$

The author of Sztuka pod dyktatura also justified the existence of censorship, the aim of which was to ensure that literature "strode the paths defined by fascism." ${ }^{90}$ The writer's admiration for the conditions created for artists by Duce was sometimes so enthusiastic that, as Mariusz Urbanek wrote, "had Waldorff's description not been so serious, one could consider it a satire." "91 The text did, in fact, sometimes include some menacing tones related to the problem of the opponents of the system still operating in some places:

Today, (...) the honest Italian oppositionist could only be a person who would honestly dare to say that he knows a person who in identical conditions would do more than Mussolini. In that sense, there is no opposition. Naturally, there are in Italy people who fight fascism regardless, yet let us agree that that is not the opposition, simply the enemies of the nation who ought to be fought as ruthlessly as possible. ${ }^{92}$

In fact, Waldorff saw some limitations of freedom, yet he seemed to think that they were justified by the nature and the extent of the transformations in Italy.

\footnotetext{
${ }^{89}$ Idem, "Sztuka pod dyktaturą. Muzyka", p. 12. [English version translated from Polish].

${ }^{90}$ As cited in: M. Urbanek, op. cit., p. 66.

${ }^{91}$ Ibid., p. 65.

92 J. Waldorff, "Sztuka pod dyktaturą", Prosto z mostu 1937, issue 54, p. 1.
} 
A painter met in a Rome café said: "I as well would prefer in Italy an atmosphere of complete freedom, just like in France. Yet not every country can afford it, and when it comes to a choice: egoistic liberalism or a strong homeland, what should I choose?"93 The answer to the question also seemed obvious to the author of the report.

Among the nationalistic authors who wrote approvingly of fascism, the highest attention to the problem of legitimacy of the limitations of civil liberties was applied by Ferdynand Goetel, an acclaimed novelist, former chairman of the PEN Club, and a member of the Polish Academy of Literature. In political terms, Goetel was associated with the Sanation camp, while his play entitled Samuel Zborowski, published in 1929, was read as an explicit support for Piłsudski's activities. It indicated the threats originating from excess civil liberties, which can lead a country to anarchy; he expressed, in Maciej Urbanowski's opinion, "a postulate for a strong state and government, but also an opposition to the abuse of freedom by individuals." 94 A type of a continuation of that matter was offered in a treatise entitled Pod znakiem faszyzmu $u^{95}$, which constituted probably the most significant text promoting the establishment in Poland of a fascist system ${ }^{96}$. Goetel's ideological programme was evidently inspired by Italian fascism, admired for "the superb iron-clad unprecedented in world history organisation of the entire society"97, which it managed to use in relation to the civilisational level of Italy. The writer viewed fascism as a kind of "bloodless revolution" performed "without a sea of blood, without cruelty and execution (...) without a row of gallows from which citizens would hang, without paralysing the entire economic and social machine." 98 The author of Kar-Chat argued that "whoever considers vio-

${ }^{93}$ Idem, "Sztuka pod dyktaturą. Caffe Greco", p. 2

${ }^{94}$ M. Urbanowski, "Wolność tragiczna? Wolność polityczna w literaturze II RP" in: idem, Od Brzozowskiego do Herberta. Studia o ideach literatury polskiej XX wieku, Wydawnictwo LTW, Warsaw 2013, p. 118.

${ }^{95}$ I discussed this text extensively in one of the chapters of my book entitled Polscy pisarze wobec faszyzmu, Wydawnictwo Uniwersytetu Łódzkiego, Lodz 2015.

${ }^{96}$ As the earliest proposal of that type developed on a large scale one should consider the brochure entitled Jak ja wyobrażam sobie faszyzm polski by fr. Zbigniew Łuczycki. It represented a traditionalist trend (anti-liberal and anti-leftist, as well as anti-Semite), and treated fascism as a means of strengthening Polish Catholicism, and traditional values: “(...) 'Instaurare omnia in Christo', is a slogan, the goal, method, and the scope of work of Polish and Catholic Fascism - it is an act, the Statute of Fascism for all its respectable dealings based on intelligence, honesty, justice, and love for our ideals, sanctitude, and the national and religious achievements" (Z. Luczycki, Jak ja wyobrażam sobie faszyzm polski, Drukarnia „Ziemiańska”, Lublin 1926, p. 13 [English version translated from Polish]). Cf. also remarks by Bogumił Grott, op. cit., pp. 39-40.

${ }^{97}$ F. Goetel, Dzieła wybrane, vol. 5: Pisma polityczne. „Pod znakiem faszyzmu” oraz szkice rozproszone 1921-1955, M. Urbanowski (ed.), Wydawnictwo Arcana, Krakow 2006, p. 51. [English version translated from Polish].

${ }^{98}$ Ibid., p. 118. 
lence without internal shame, he has surely lost any sense of humanity"99, yet he defended the right to use compulsion - even though temporary ${ }^{100}$ - by the fascist state (thus also by the future Polish state). But he knew well how much Poles were attached to their sense of freedom:

A certain characteristic cult of strength and the admiration of power inclines us to favour the principle of strong government based on respect for authority. At the same time, though, we do not wish to agree to anything which would diminish our rights and liberties. And, most of all, we are sensitive to compulsion. Not through violence! Everything through internal conviction! Actually, it should be said that the sense of personal and civil liberty would be a wonderful feature of Poles if it were accompanied a similarly high sense of civil duty. Yet the circle of dutifulness which characterises (...) the societies of France and England, in Poland is fragile and thin, and breaks under the slightest pressure of insatiable jobbery ${ }^{101}$.

Goetel emphasised the Polish national nature formed in special historical circumstances, and how it differed, disadvantageously, from the nature of Western societies:

Have those who are so willing to blind us with the enlightened West ever considered how much compulsion is included in the French, English or Scandinavian morality - compulsion achieved in the heavy, long, and hard lessons offered by history? Civil liberties in those countries are countered with moral dutifulness included in virtues unknown amongst us, such as: appropriateness, reliability, honest conduct in business or interpersonal relations, diligence, and the sense of hierarchy! $!^{102}$

The Polish sense of freedom and liberty has never been countered by civil virtues. Goetel seemed to suggest that those positively evaluated features could be introduced by fascism which, in fact, "limited people's liberty in deciding about themselves, but it also deprived them of the ability to decide about the liberty of others." ${ }^{103}$ For the author of $Z$ dnia na dzien, a much more vital problem seemed the abuse of freedom by citizens than its limiting by the state. Additionally, democratic freedom, by offering everyone equal opportunities, results in

\footnotetext{
${ }^{99}$ Ibid., p. 120.

100 "The course of events in fascist states also indicates a continuous process of tempering acute methods of compulsion" (ibid., p. 120); "While the only argument in support of the legitimacy of violence can only be that eventually it becomes unnecessary" (ibid.).

101 Ibid., pp. 120-121.

102 Ibid., p. 122.

${ }^{103}$ Ibid., p. 127.
} 
a victory of the "cunning and the greedy"104, while it encumbers ordinary people "with the burden of civilisational concerns (...) without offering them any uniform directions as to how to solve them." 105 In that approach, fascism becomes a type of "escape from freedom", which, in excess, proves detrimental both for the individual, and the entire society. A significant weakness of democracy has always been its intention to impose "on the masses truths and doctrines invented in the laboratories of social activists." Instead, "fascism (...) reached for the truths of the masses, and approached them as its own. The truths of the masses were simpler, more modest, maybe more brutal (...) But they were also more honest, natural, and more human."106

The nationalistic reception of Italian fascism, though abundant quantitatively, was usually rather superficial. As Bogumił Grott noted, National Democratic articles of that period were marked with a "complete lack of reflection (...) on the doctrine foundations of the system, which in their centre included the concept of the state, so also the problem of its rule in relation to external factors." ${ }^{107}$ That observation could be extrapolated onto the entirety of the nationalist press articles of the interwar period, which was not necessarily marked by considerable insightfulness in their interpretations of Italian reality. The fascist doctrine was often considered superficially, without the proper appreciation for the significance of the concept of a totalitarian state, which constituted the core of Mussolini's and Gentile's idea. The discussions of the limiting of civil liberties introduced by fascists were also burdened with similar weaknesses, and probably no nationalist interested in fascism found strength to approach it as systematically as Karol Ludwik Koniński, the author of a several-volume-long study devoted to the legitimacy of the application of compulsion by the state. ${ }^{108}$ That observation did not mean, however, that nationalistic journalists neglected that topic.

The material presented herein indicates that the issue of freedom in a fascist system was interpreted in nationalistic press articles according to several different methods:

\footnotetext{
104 Ibid.

${ }^{105}$ Ibid., p. 126.

${ }^{106}$ Ibid., p. 127.

${ }^{107}$ B. Grott, op. cit., p. 155.

${ }^{108}$ Koniński, though it would be difficult to define him as a liberal journalist, expressed a conviction, so close to the classics of English liberal thought, that the state must ensure its citizens "a legally warranted circle of liberties, security, and dignity; a circle which no one can break without becoming subject to punishment" (K.L. Koniński, "Humanizm, godność, demokracja" in: idem, Pisma polityczne, M. Urbanowski (ed.), Wydawnictwo Arkana, Krakow 2014, p. 466. Originally printed in: Zwrot 1937 , issue 21$)$.
} 
1. ND journalists rejected the concepts of liberal freedom, neither did they support totalitarianism, though they usually did not express any firm opposition towards violence. They seemed to be inclined towards the anti-liberal concept of the "intellectual limitation of freedom" in the name of introducing social order, yet they feared a degenerated shape of authoritarianism in the form of a police state imposing excessive collectivism.

2. Karol Zbyszewski and Adolf Nowaczyński were clearly favourably disposed to anti-liberal repressions directed against undesired groups (mainly Jews). They argued that in a national state only the representatives of the dominant nation are entitled to political and creative freedom, while the rights of minorities should be limited as much as possible. The implementation of such a policy by fascists was accepted by many, who wanted to transfer similar solutions to Poland.

3. For some authors (mainly Goetel, also Łaszowski), limiting freedom appeared as a price which was worth paying (and should be paid) considering the positive values associated with fascism (the strengthening of the state, social mobilisation, and the adjustment of the national character of Poles). That issue was presented as a decreasing inconvenient cost, which would diminish as the fascist system became more liberal. Such a conviction seemed edging on the absolutist position which stated that it is possible and necessary to calculate the actual cost worth incurring in the name of the abstract future happiness.

4. The final interpretative model indicated that fascism did not, in fact, limit freedom, or the limitations were insignificant, not really severe, and basically socially beneficial. Such an attitude was shared by Jerzy Waldorff, the author of Sztuki pod dyktatura, who referred in his observations mainly to the freedom of artistic expression. He focussed less on the problem of political freedom; Waldorff's admiration for the civilisational achievements of fascist Italy (such as draining the Pontine Marshes) did not leave much space for any reflection on that problem. Władysław Jabłonowski also wrote about "significant freedoms", of which, unlike the abstract ones, not actually desired by citizens, there is in Italy "much more (...) than in the so-called democratic states, where the charming freedom tree was plucked of all its leaves, and is drying out hopelessly." 109

It should be noted, though, that the most radical praise of fascist freedom was expressed not in a press article but in a poetic work. Artur Maria Swinarski's frenetic poetry called for the creation of a new culture on the rubble of the old world, giving the youth ${ }^{110}$, personified by "boys in black shirts", the right to freely express their creative freedom:

\footnotetext{
${ }^{109}$ W. Jabłonowski, Italia żyjąca, p. 294.

${ }^{110}$ Swinarski's vision corresponded to the fascist perception of youth considered as an exceptional and privileged period of one's life. The issue was discussed by Piotr Podemski in a book entitled Giovinezza. Młodzież i mit młodości w faszystowskich Włoszech, Wydawnictwo DiG, Warsaw 2010.
} 
Gentlemen! Why, when today the sun is fainting and smouldering,

Why do you pore over Schiller's skull and parchment?

Each of you is a creator! All your hearts neigh like colts

And each of us has a pair of hands.

Let us build our own Capitol and our own Forum,

Let us build from iron and mind an eternal ode -

There are so many forms in rocks waiting to be born,

While hands and hammers are young! ${ }^{111}$

\section{Bibliography}

Amica Italia. Polscy prawnicy wobec włoskiego faszyzmu 1922-1939. Wybór pism, Maciej Marszał (ed.), Księgarnia Akademicka, Krakow 2004.

As [Antoni Słonimski], "Sztuki o Koperniku i Villonie", Wiadomości Literackie 1937, issue 26, p. 5.

Bednarczuk Monika, "Metafory faszyzmu (o polskich konceptualizacjach włoskiej doktryny)", Przeglad Humanistyczny 2011, issue 1, pp. 17-31.

Berlin Isaiah, Dwie koncepcje wolności i inne eseje, J. Jedlicki (ed.), trans. H. Bartosiewicz et al., Res Publica, Warsaw 1991.

Borejsza Jerzy Wojciech, Mussolini byt pierwszy..., Czytelnik, Warsaw 1989.

Borejsza Jerzy Wojciech, Rzym a wspólnota faszystowska, Książka i Wiedza, Warsaw 1981.

Doktryny polityczne XIX i XX wieku, K. Chojnicka i W. Kozub-Ciembroniewicz (eds.), Wydawnictwo Uniwersytetu Jagiellońskiego, Krakow 2000.

Domagalska Małgorzata, Antysemityzm dla inteligencji? Kwestia żydowska w publicystyce Adolfa Nowaczyńskiego na łamach „Myśli Narodowej” (1921-1934) i „Prosto z mostu” (1935-1939) (na tle porównawczym), Żydowski Instytut Historyczny, Warsaw 2004.

Gentile Emilio, Początki ideologii faszystowskiej (1918-1925), trans. Tomasz Wituch, Wydawnictwa Uniwersytetu Warszawskiego, Warsaw 2011.

Grott Bogumił, Dylematy polskiego nacjonalizmu. Powrót do tradycji czy przebudowa narodowego ducha, Wydawnictwo Von Borowiecky, Warsaw 2014.

Grott Olgierd, Faszyści i narodowi socjaliści w Polsce, Zakład Wydawniczy Nomos, Krakow 2007.

Eatwell Roger, Faszyzm. Historia, trans. Tomasz Oljasz, Dom Wydawniczy Rebis, Poznan 1999.

Estetyka dyskursu nacjonalistycznego w Polsce 1926-1939, U. Schmid (ed.), Wydawnictwo Naukowe Scholar, Warsaw 2014.

Eysymont Henryk, "O ideał ustroju. Polemika z powodu artykułu 'Monarchia czy państwo narodowe'”, Myśl Narodowa 1936, issue 19, pp. 291-292.

Faszyzm, in: Encyklopedia biatych plam, t. 6, Polskie Wydawnictwo Encyklopedyczne, Radom 2001, pp. 61-122.

Frycz Karol Stefan, “Na widowni”, Myśl Narodowa 1939, issue 18, pp. 265-266.

111 A.M. Swinarski, “Giovinezza” in: idem, Eja! Eja! Alala!... As cited in: Estetyka dyskursu nacjonalistycznego w Polsce 1926-1939, U. Schmid (ed.), Wydawnictwo Naukowe Scholar, Warsaw 2014, p. 281. [English version translated from Polish]. 
Goetel Ferdynand, Dzieła wybrane, t. 5: Pisma polityczne. „Pod znakiem faszyzmu” oraz szkice rozproszone 1921-1955, Maciej Urbanowski (ed.), Wydawnictwo Arcana, Krakow 2006.

Jabłonowski Władysław, Amica Italia. Rzecz o faszyzmie. Wrażenia i rozważania, Księgarnia Świętego Wojciecha, Poznan 1926.

Jabłonowski Władysław, "Italia żyjąca”, Myśl Narodowa 1937, issue 19, pp. 292-294.

Jesionowski Alfred, “Zbrojenie kulturalne Italii”, Prosto z mostu 1938, issue 10, p. 7.

Korolec Jan, “Czy słowo zaklęcia będzie wypowiedziane po polsku”, Prosto z mostu 1935, issue 3, p. 4.

Kotowski Albert S., Narodowa Demokracja wobec nazizmu i Trzeciej Rzeszy, Wydawnictwo Adam Marszałek, Torun 2007.

Kozub-Ciembroniewicz Wiesław, Doktryna i system władzy Włoch faszystowskich na tle porównawczym, Wydawnictwo Uniwersytetu Jagiellońskiego, Krakow 2010.

Kwiatkowski Jerzy, Dwudziestolecie międzywojenne, Wydawnictwo Naukowe PWN, Warsaw 2000.

Lew Anna, "Fascynacja czy akceptacja? Włoski faszyzm w poglądach Władysława Jabłonkowskiego", in: Narodowa Demokracja XIX-XXI wiek. Dzieje ruchu politycznego, t. 1: Koncepcje - ludzie, Tomasz Sikorski, Adam Wątor (eds.), Wydawnictwo Adam Marszałek, Toruń 2012.

Łaszowski Alfred, “Analiza łez krokodylich”, Prosto z mostu 1937, issue 47, p. 2.

Łuczycki Zdzisław, Jak ja wyobrażam sobie faszyzm polski, Drukarnia „Ziemiańska”, Lublin 1926.

Marszał Maciej, "Polskie elity wobec włoskiego faszyzmu 1922-1939”, Annales Universitatis Mariae Curie-Skłodowska. Sectio G, Ius 2011, issue 58, pp. 121-137.

Meller Arkadiusz, “'Sztuka pod dyktaturą’ Jerzego Waldorffa - szkic o relacjach między faszyzmem a kulturą na przykładzie Włoch Benito Mussoliniego", Historia i Polityka 2009/2010, issue 2/3, pp. 105-121; Akademicka Platforma Czasopism [online:] http://apcz.pl/czasopisma/index.php/HiP/article/view/HiP.2010.007/1357 (accessed on: 10.02.2016).

Nowaczyński Alfred, Cezar i człowiek, Gebethner i Wolff, Warsaw 1937.

Nowaczyński Alfred, “Ofensywa. Caliban zabił Ariela”, Myśl Narodowa 1930, issue 45, p. 715.

Nowaczyński Alfred, “Ofensywa. Sempre Avanti”, Prosto z mostu 1939, issue 10, p. 8.

Peretiakowicz Alfred, Państwo faszystowskie: bilans rządów pięcioletnich, Dom Książki Polskiej, Warsaw 1927.

Piasecki Stanisław, “Trzy morza a nie jedno”, Prosto z mostu 1939, issue 27, p. 1.

Piestrzyński Ryszard, "Państwo absolutystyczne i jego zwyrodnienie”, Myśl Narodowa 1933, issue 13, 161-163.

Podemski Piotr, Giovinezza. Młodzież i mit młodości w faszystowskich Włoszech, Wydawnictwo DiG, Warsaw 2010.

Rembieliński Jan, “Na widowni”, Myśl Narodowa 1934, issue 1, pp. 10-11.

Rudnicki Szymon, Obóz Narodowo-Radykalny. Geneza i działalność, Spółdzielnia Wydawnicza „Czytelnik”, Warsaw 1985.

Rybarski Roman, "Polityka gospodarcza faszyzmu”, Gazeta Warszawska Poranna 1926, issue 190.

Reprint: Amica Italia. Polscy prawnicy wobec wtoskiego faszyzmu 1922-1939. Wybór pism, M. Marszał (ed.), Księgarnia Akademicka, Cracow 2004, pp. 51-58.

Rybarski Roman, “O dyktaturach”, Myśl Narodowa 1927, issue 21, 381-382.

Rybarski Roman, “O państwie policyjnym”, Myśl Narodowa 1933, issue 20, 273-275. 
Sondel-Cedarmas Joanna, Nacjonalizm włoski. Geneza i ewolucja doktryny politycznej (1896-1923), Księgarnia Akademicka, Krakow 2013,

Swinarski Artur Maria, Eja! Eja! Alala!, Instytut Wydawniczy „Arena”, Warsaw 1926.

Urbanek Mariusz, Waldorff. Ostatni baron Peerelu, Wydawnictwo Iskry, Warsaw 2008.

Urbanowski Maciej, Oczyszczenie: szkice o literaturze polskiej XX wieku, Wydawnictwo Arcana, Krakow 2002.

Urbanowski Maciej, Od Brzozowskiego do Herberta. Studia o ideach literatury polskiej XX wieku, Wydawnictwo LTW, Warsaw 2013.

Waldorff Jerzy, "Sztuka pod dyktaturą. Architektura", Prosto z mostu 1938, issue 8, p. 2.

Waldorff Jerzy, "Sztuka pod dyktaturą. Caffe Greco", Prosto z mostu 1938, issue 14, p. 2.

Waldorff Jerzy, "Sztuka pod dyktaturą. D’Annunzio - Marinetti”, Prosto z mostu 1937, issue 55, p. 3.

Waldorff Jerzy, "Sztuka pod dyktaturą. Muzyka", Prosto z mostu 1937, issue 57/58, p. 12.

Waldorff Jerzy, "Sztuka pod dyktaturą. Rzeźba włoska", Prosto z mostu 1938, issue 6, p. 3.

Waldorff Jerzy, "Sztuka pod dyktaturą. Teatr włoski”, Prosto z mostu 1938, issue 17, p. 3.

Zbyszewski Karol, "Ryżową szczotką. Blok zdrowego sensu”, Prosto z mostu 1938, issue 39, p. 8.

Paweł Sobczak

\section{Intellectual limitation of freedom? The issues of libertas in the nationalistic reception of Italian fascism in the Second Polish Republic}

\section{(Summary)}

The limiting of personal freedom in interwar Italy resulted directly from the fascist approach to the state-individual relationship. The idea of leaving the citizens the broadest individual freedom, and limiting state law activities to the minimum was completely alien to fascist ideologies. The goal of the article was to consider how the problem of freedom in a fascist state was treated by right-wing supporters of that ideology in Poland. For the analysis, I use, e.g. the journalism of W. Jabłonkowski (Amica Italia), R. Rybarski (articles published in Myśl Narodowa), A. Łaszowski (Analiza łez krokodylich), K. Zbyszewski (a column series Ryżowa szczotka), A. Nowaczyński (Sempre avanti), J. Waldorff (Sztuka pod dyktatura), and F. Goetel (Pod znakiem faszyzmu). As the interpretative context, I also used the poetry of A.M. Swinarski, and a play by Nowaczyński entitled Cezar i czlowiek.

Keywords: fascism, nationalism, ideology, freedom, interwar period 